\title{
BIPOLAR AFFECTIVE DISORDER AND DISSOCIATION - COMPARISON WITH HEALTHY CONTROLS
}

\author{
Klara Latalova ${ }^{a *}$, Jan Prasko a,b,c, Petr Pastuchaa,d, Ales Grambal ${ }^{\mathrm{a}}$, Dana Kamaradova ${ }^{\mathrm{a}}$, \\ Tomas Divekya, Daniela Jelenova ${ }^{a}$, Barbora Mainerova ${ }^{a}$, Kristyna Vrbova ${ }^{a}$ \\ a Department of Psychiatry, Faculty of Medicine and Dentistry, Palacky University Olomouc and University Hospital Olo- \\ mouc, Czech Republic \\ b Prague Psychiatric Centre, Ustavni 91, 18103 Praha \\ c Centre of Neuropsychiatric Studies, Ustavni 91, 18103 Praha \\ d Outpatient Department of Psychiatry, U Nemocnice 70, 75701 Valasske Mezirici \\ E-mail:klaralat@centrum.cz
}

Received: June 9, 2010; Accepted: November 10, 2010

Key words: Bipolar disorder/Healthy controls/Dissociation/Onset of the disorder

Introduction. According to recent findings, certain clinical symptoms of patients suffering from affective and anxiety disorder can be related to dissociation. The aim of our study was to examine if the level of dissociation in bipolar affective disorder differed from the level of dissociation in healthy volunteers.

Methods. 41 patients suffering from bipolar disorder (51.2\% females), and 198 healthy controls $(71.2 \%$ females) were included in the study. The patients with bipolar affective disorder in remission were recruited from the Outpatient department of the Department of Psychiatry of the University Hospital Olomouc. They were psychiatrically assessed and the state of the disorder was evaluated by an experienced psychiatrist. Only patients in remission, evaluated as 1 or 2 points of clinical global impression - severity scale, were included in the study. All participants were assessed with the Dissociative Experiences Scale (DES).

Results. There were no differences in the two groups in demographic variables like age, gender and education. Patients had a significantly higher mean score on the DES and pathological DES than healthy controls.

Conclusion. Our results suggest that the level of psychological dissociation in bipolar affective patients is higher than in healthy controls.

\section{INTRODUCTION}

Bipolar affective disorder is a severe and often disabling condition. The lifetime prevalence of type I BPD is approximately $1.2 \%$ but including type II, cyclothymia, juvenile variants and proposed "bipolar spectrum" disorders this yields total rates of at least $5 \%$ (ref. ${ }^{1}$ ). Dissociation is a human capacity that fulfills an adaptive or maladaptive function under specific circumstances. Dissociation as a clinical psychiatric condition has been defined primarily in terms of the fragmentation and splitting of the mind and perception of the self and the body. Its clinical manifestations are altered perceptions and behavior, including derealization, depersonalization and distortions of the perception of time, space and body.

Several studies have confirmed the close association between depressive symptoms and dissociation ${ }^{2-5}$. Acute dissociation is also associated with panic symptoms that occur during a traumatic episode. Dissociation is seen as a coping strategy for dealing with strong anxiety states and painful trauma experiences ${ }^{6,7}$. Although there are contradictory findings, dissociative symptoms have also been reported in patients with schizophrenia ${ }^{8-11}$. Based on clinical phenomenology and childhood trauma history, Ross ${ }^{6}$ proposed a dissociative subtype of schizophrenia. Childhood trauma scores were correlated with dissociation scale scores and dissociative symptom clusters, but not with core symptoms of the schizophrenic disorder ${ }^{12}$. High level of dissociation is typical for patients with borderline personality disorders ${ }^{5,13}$. The level of dissociation can be one of the reasons for treatment resistance in panic disorder patients ${ }^{14-16}$, as well as in the case of patients suffering from $\mathrm{OCD}^{17-19}$. Dissociation might be a predictor of negative treatment outcome in cognitive-behavioural therapy for patients with anxiety disorders ${ }^{10}$ and obsessive compulsive disorder ${ }^{20}$. Higher level of dissociation also predicts poorer outcome in inpatients with affective, anxiety and somatoform disorders participating in brief psychodynamic psychotherapy ${ }^{10}$. It is suggested that dissociative subjects dissociate as a response to negative emotions arising in psychotherapy leading to a less favorable outcome. Additionally, dissociative patients may have an insecure attachment pattern negatively affecting the therapeutic relationship. Thus, dissociation may directly and indirectly influence the treatment process and outcome.

Although mood disturbances are a sine qua non of bipolar disorder, contemporary research has pointed increasingly to non-affective elements of psychopathology associated with the diagnosis. Problems with work and social functioning persist for lengthy periods in many patients with bipolar disorder after the resolution of manic or depressive episodes, even in the absence of subsyndro- 
mal affective symptoms ${ }^{21,22}$. These problems point to other factors that likely mediate functional recovery, including the ability to plan and think clearly, understand connections between everyday life situations and emotions, solve problems with understanding of the context of the situation, use emotions as a tool for understanding interpersonal situations, remember important information and others which can be problematic if a person dissociates. Nothing is reported in the literature on dissociation in bipolar disorders, although the history of neglect, abuse or trauma is evident in nearly half of adults with bipolar disorder ${ }^{23}$

Goals: The aim of our study was to examine if the level of dissociation in patients with bipolar affective disorder differed from the level of the dissociation in healthy controls and if the level of dissociation was related to demographic variables, like age, time of onset of the disorder, duration of the disorder, number of suicidal attempts or medication level.

Hypothesis: We hypothesized that patients with bipolar affective disorder suffered from higher levels of dissociation than healthy controls, and that the level of dissociation is associated with the earlier age of onset, with higher level of suicidality, and with higher dosages of antipsychotic.

\section{METHODS}

Forty-one patients with bipolar affective disorder and 198 healthy controls were included in the study.

\section{Inclusion criteria for the patients}

a) ICD-10 research criteria for bipolar affective disorder

b) Age 17-70 years;

c) Male and female;

d) Clinical global impression - severity CGI-S ${ }^{24}$ one or two.

\section{Exclusion criteria:}

a) Cognitive disorders and mental disorders due to a general medical conditions

b) Schizophrenia or delusional disorder in history;

c) Substance dependence;

d) Serious somatic disease;

Assessment: Psychological dissociative symptoms were examined using the Dissociative Experiences Scale $(\mathrm{DES})^{25,26}$. The DES is a self-administered 28-item inventory of psychological dissociation, where participants are asked to indicate on a visual analog scale how often they experience the dissociative symptoms (in percentage of time). The Czech version of the scale is comparable to the original version in terms of its test-retest reliability, validity and factor structure ${ }^{27}$. Pathological DES was measured by a Dissociative Experiences Scale Taxon (DES-T) ${ }^{28}$ based on the items of DES number 3, 5, 7, 8, 12, 13, 22, and 27 . These items measure identity alteration, depersonalization, derealization, discontinuation of awareness, dissociative amnesia and auditory hallucinations.
Ethical issues: Investigation was carried out in accordance with the latest version of the Declaration of Helsinki and ICH-GCP guidelines (International Conference on Harmonization, Good Clinical Practice, 1997). All participants signed an informed consent before entering the study. The study was approved by a local Ethical Committee. Mean demographic and clinical variables, like scores in DES, pathological DES, number of hospitalizations and suicidal attempts are in Table 1.

Participants: 41 patients with bipolar affective disorder between 22 and 72 years of age (51.2\% females; mean age $44.4 \pm 13.13$ ) from the Outpatient department of Psychiatry Clinic of University Hospital Olomouc were recruited for this study. All patients used psychotropic medication, mood stabilizers and or antipsychotics. In the case of antipsychotics doses equivalent to $100 \mathrm{mg} /$ day of chlorpromazine were $2 \mathrm{mg}$ /day for risperidone, $5 \mathrm{mg} /$ day for olanzapine, $75 \mathrm{mg} /$ day for quetiapine, $60 \mathrm{mg} /$ day for ziprasidone and $7.5 \mathrm{mg} /$ day for aripiprazole ${ }^{29}$. In the case of mood stabilizers we calculated equivalents of basic doses of mood stabilizers (for lithium $900 \mathrm{mg} /$ day, for divalproex $1000 \mathrm{mg} /$ day, for lamotrigine $200 \mathrm{mg} /$ day) as one. Reported minimum effective dose equivalence ratios to haloperidol were then converted to chlorpromazine equivalents using the " $2 \mathrm{mg}$ of haloperidol equals $100 \mathrm{mg}$ of chlorpromazine” (average haloperidol equivalent dose of quetiapine was $9.4 \mathrm{mg} /$ day, $4.3 \mathrm{mg}$ for olanzapine, $5.0 \mathrm{mg}$ for risperidone, $3.3 \mathrm{mg}$ of ziprasidon and $4.25 \mathrm{mg}$ for aripiprazole). One hundred ninety eight healthy controls ( $71.2 \%$ females) without any lifetime Axis I psychiatric diagnosis were recruited through local advertisement. The controls were aged between 22 and 68 years (mean age $41.25 \pm 13.2$ years). None used any psychotropic medication.

Data analysis: Patient demographic and baseline clinical characteristics were analyzed using column statistics. Normal distribution of the demographic and clinical variables was determined by the Shapiro-Wilk W test, with the exception of DES and pathological DES in healthy volunteers group. Differences between patients with bipolar affective disorder and healthy controls were analyzed using unpair t-tests for independent groups and the Mann-Whitney test. The relationships between variables with normal distribution were calculated using Pearson correlation analysis, while Spearman correlation was used for variables with non-normal distribution of DES. The level of significance was set at $\mathrm{p}<0.05$. All analyses were conducted using STATISTICA 7.0 software.

\section{RESULTS}

Sociodemographic and clinical variables and the frequency of dissociative experiences in patients with bipolar affective disorder and healthy controls

Comparisons of the sociodemographic and clinical characteristics of bipolar affective disorder patients and controls are shown in Table 1. No significant age differences were found between the groups. There were statistically significant differences between patients with 
bipolar disorder and healthy controls in terms of gender ratio and education level. There were no statistical differences in DES between males and females in the controls and no statistical differences in DES in gender in patient groups (both unpair t-tests: ns.). There were no differences in DES and in pathological DES in relation to levels of education either in healthy controls (both Kruskal-Wallis test; n.s.) or in patients (both Kruskal-Wallis test; n.s.) but there were statistically significant difference at each educational level in DES and pathological DES between controls and patients.

Patients had a higher mean DES score than controls (means: $31.89 \pm 7.12$ and $21.28 \pm 19.7$; Mann Whitney
$\mathrm{U}$ test $\mathrm{p}<0.0001)$; and higher score of pathological DES than controls (means: $8.22 \pm 2.19$ and $2.50 \pm 4.40$; Mann Whitney test $\mathrm{p}<0.0001)$.

There were no statistically significant DES differences between control males and males with bipolar disorder (unpaired t-test; $p=0.055$ ) but there were statistically significant difference between female controls and female bipolar patients (Mann Whitney test: $p<0.0001$ ). There were highly statistically significant differences between males and females in the control group and patients in terms of pathological DES (both: Mann Whitney test: $\mathrm{p}<0.0001)$.

Table 1. Mean demographic and clinical variables.

\begin{tabular}{|c|c|c|c|}
\hline & $\begin{array}{l}\text { Bipolar affective } \\
\text { disorder }(n=41)\end{array}$ & $\begin{array}{l}\text { Controls } \\
(n=198)\end{array}$ & $\begin{array}{l}\text { Statistical } \\
\text { significance }\end{array}$ \\
\hline Age (years) & $44.05 \pm 14.45$ & $41.25 \pm 13.20$ & $\mathrm{~ns}^{2}$ \\
\hline Gender: male / female & $20 / 21$ & $58 / 141$ & $\mathrm{p}<0.05^{3}$ \\
\hline Education (basic/secondary/university) & $7 / 26 / 8$ & $12 / 120 / 68$ & $\mathrm{p}<0.05^{1}$ \\
\hline Age of the onset of the disorder & $30.20 \pm 9.71$ & - & \\
\hline Duration of the disorder & $13.61 \pm 9.48$ & - & \\
\hline Number of illness phases & $4.59 \pm 2.21$ & - & \\
\hline Number of hospitalizations & $2.00 \pm 1.70$ & - & \\
\hline Number of suicidal attempts & $0.32 \pm 0.65$ & - & \\
\hline $\begin{array}{l}\text { Frequency in per cent/mean dosage of the } \\
\text { thymostabilisers usage (mood stabilizers } \\
\text { equivalent) }\end{array}$ & $82.9 \% / 0.93 \pm 0.61$ & - & \\
\hline $\begin{array}{l}\text { Frequency in per cent/mean dosage of the } \\
\text { antipsychotic usage (haloperidol equivalent) }\end{array}$ & $68.3 \%$ / $3.39 \pm 3.51$ & - & \\
\hline $\begin{array}{l}\text { Frequency in per cent of antidepressants } \\
\text { usage }\end{array}$ & $46.3 \%$ & - & \\
\hline DES (mean) & $31.89 \pm 7.12$ & $21.28 \pm 19.70$ & $\mathrm{p}<0.0001^{4}$ \\
\hline Pathological DES (mean) & $8.22 \pm 2.19$ & $2.50 \pm 4.40$ & $\mathrm{p}<0.0001^{4}$ \\
\hline DES higher than 30 & $21(51.2 \%)$ & $47(23.7 \%)$ & $\mathrm{p}<0.05^{3}$ \\
\hline DES males (mean) & $30.30 \pm 7,22$ & $20.83 \pm 21.24$ & n.s. $(p=0,055)^{2}$ \\
\hline DES females (mean) & $33.40 \pm 6.84$ & $21.47 \pm 19.11$ & $\mathrm{p}<0.0001^{4}$ \\
\hline Pathological DES males (mean) & $7.97 \pm 2.25$ & $3.16 \pm 4.81$ & $\mathrm{p}<0.0001^{4}$ \\
\hline Pathological DES females (mean) & $8.47 \pm 2.16$ & $2.23 \pm 4.21$ & $\mathrm{p}<0.0001^{4}$ \\
\hline DES - people with basic education & $36.12 \pm 9.75$ & $19.04 \pm 16.97$ & $\mathrm{p}<0.05^{2}$ \\
\hline DES - people with secondary school & $31.18 \pm 6.88$ & $20.49 \pm 19.44$ & $\mathrm{p}<0.0001^{4}$ \\
\hline DES - people with university education & $30.49 \pm 4.10$ & $23.12 \pm 20.75$ & $\mathrm{p}<0.05^{4}$ \\
\hline $\begin{array}{l}\text { Pathological DES - people with basic } \\
\text { education }\end{array}$ & $8.50 \pm 3.31$ & $3.04 \pm 4.29$ & $\mathrm{p}<0.05^{2}$ \\
\hline $\begin{array}{l}\text { Pathological DES - people with secondary } \\
\text { school }\end{array}$ & $8.12 \pm 2.06$ & $2.31 \pm 3.90$ & $\mathrm{p}<0.0001^{4}$ \\
\hline $\begin{array}{l}\text { Pathological DES - people with university } \\
\text { education }\end{array}$ & $8.32+1.70$ & $2.76 \pm 5.27$ & $\mathrm{p}<0.0005^{4}$ \\
\hline
\end{tabular}

Results are reported as account or mean \pm SD; Abbreviations: DES - Dissociative Experiences Scale,

$\mathrm{n}$ - non significant ; ${ }^{1}$ - Pearson's chi-squared test; ${ }^{2}$ - Unpaired t-test; ${ }^{3}$ - Fisher's exact test; ${ }^{4}$-Mann Whitney test 


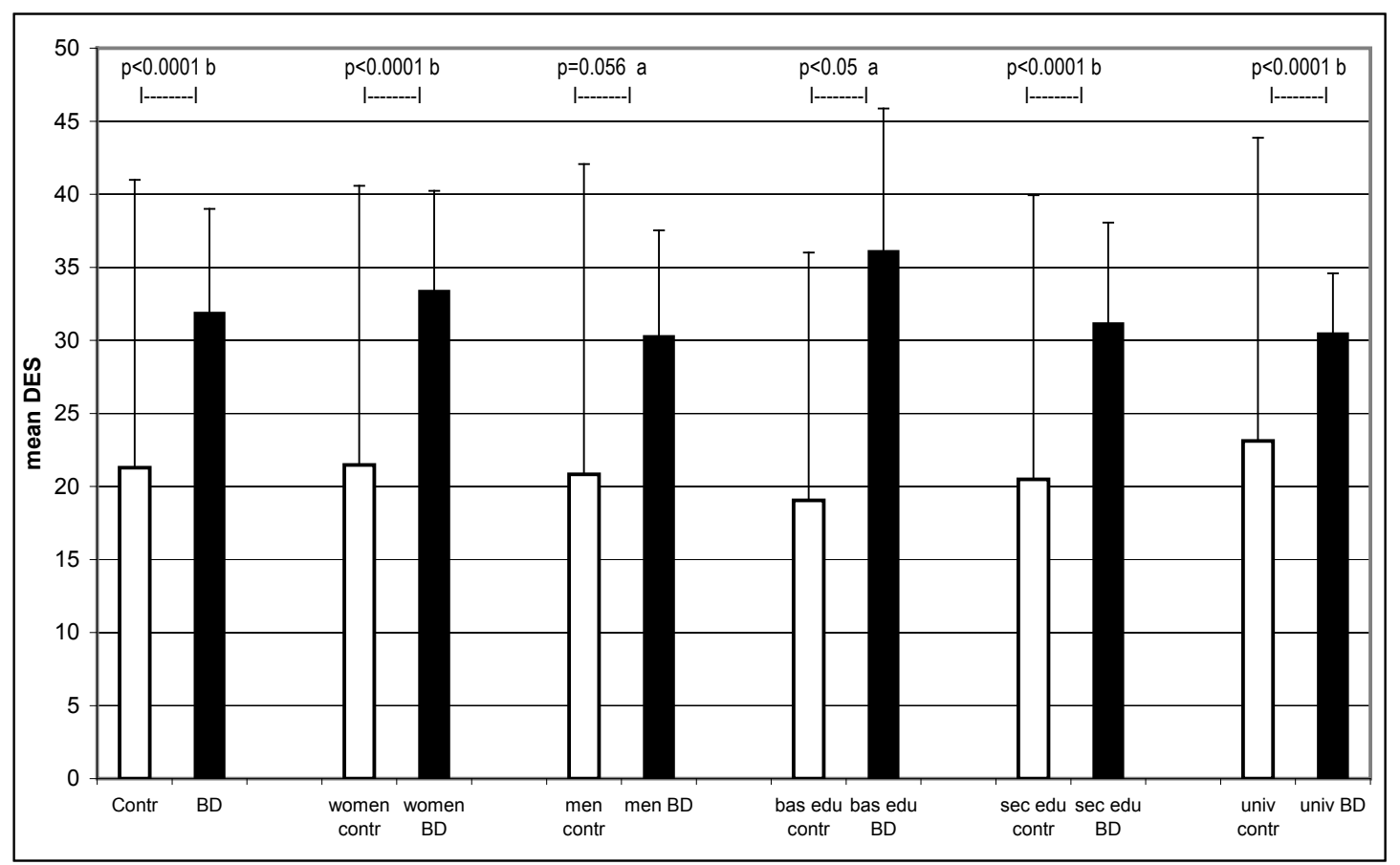

a - Unpaired t-test; b - Mann Whitney test

Fig. 1. Mean DES scores in health controls and patients with bipolar disorder.

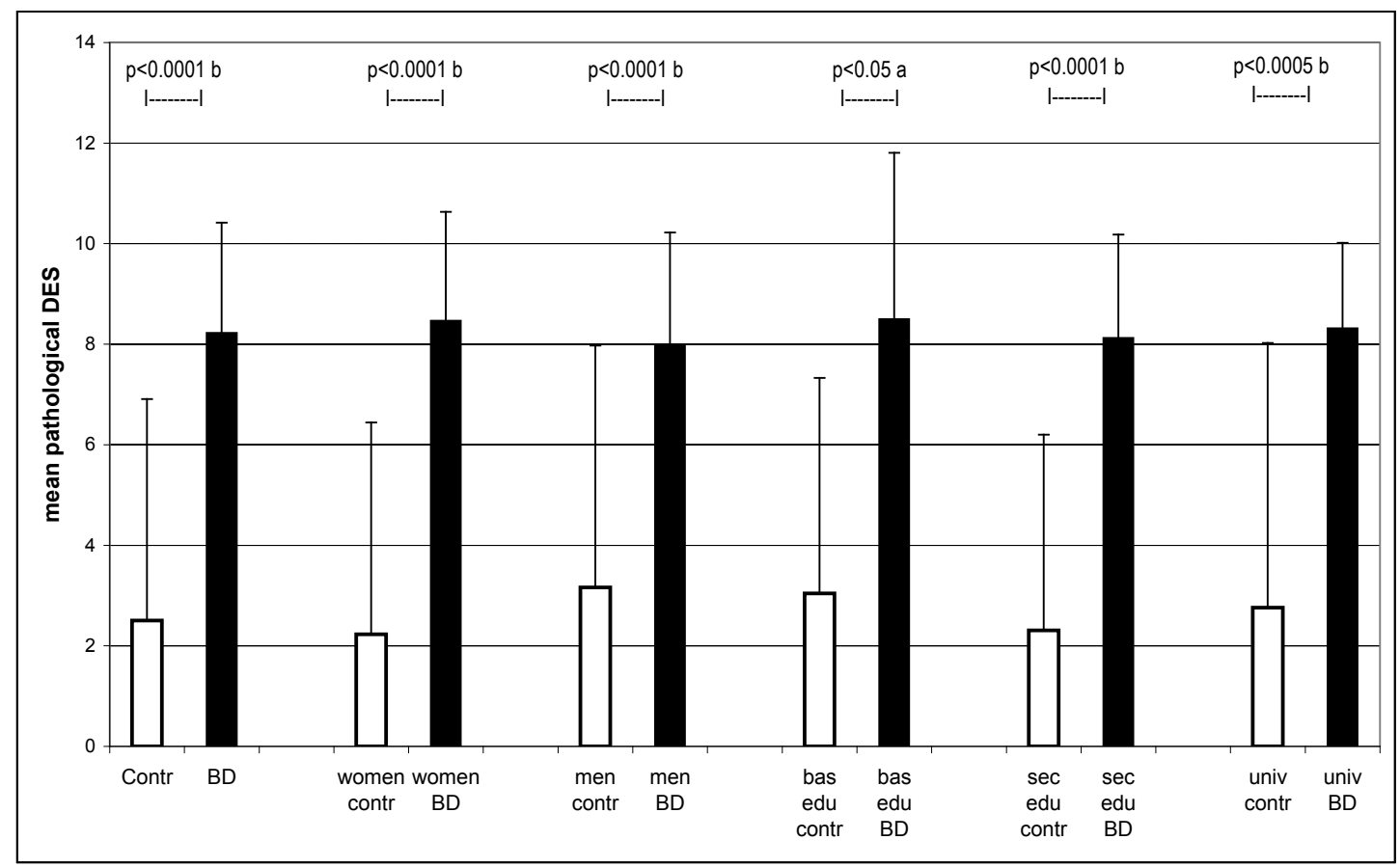

a - Unpaired t-test; b - Mann Whitney test

Fig. 2. Mean pathological DES scores in health controls and patients with bipolar disorder.

The number of patients who had experienced severe dissociative states was more frequent in patients: 21 patients $(51.2 \%)$ and 47 healthy participants (23.7\%) scored higher than 30 on the DES scale, which is the cut-off point for severe dissociation (Fisher's exact test; $\mathrm{p}<0.05$ ).

Pearson's and Spearman's correlations are presented in Table 2. Relatively strong negative asso- ciations between onset of the disorder and pathological DES were found (Pearson $r=-0.4097 ; p<0.001$ ). If the symptoms of the disorder began at a younger age, the mean score of pathological DES (DES-taxon) was higher. The onset of the disorder also correlated positively to the number of past suicidal attempts (Spearman $\mathrm{r}=0.312$; $\mathrm{p}<0.05)$ : the older the age at onset, the greater the number of suicide attempts. 
Table 2. Pearson's and Spearman's correlation coefficients between DES, pathological DES and clinical variables of bipolar affective disorder patients.

\begin{tabular}{|l|c|c|c|c|c|c|}
\hline \multicolumn{1}{|c|}{ Variables } & $\begin{array}{c}\text { Age of the } \\
\text { disorder onset }\end{array}$ & $\begin{array}{c}\text { Duration of } \\
\text { the disorder }\end{array}$ & $\begin{array}{c}\text { Age of the } \\
\text { patient }\end{array}$ & $\begin{array}{c}\text { Number of } \\
\text { suicidal } \\
\text { attempts }\end{array}$ & $\begin{array}{c}\text { Mean dosage } \\
\text { of thymostabi- } \\
\text { lisers }\end{array}$ & $\begin{array}{c}\text { Mean dosage } \\
\text { of antipsy- } \\
\text { chotics }\end{array}$ \\
\hline DES & ${ }^{\mathrm{P}}-0,2301$ & ${ }^{\mathrm{P}} 0,1021$ & ${ }^{\mathrm{P}}-0,07588$ & ${ }^{\mathrm{S}}-0,08439$ & ${ }^{\mathrm{S}} 0,1892$ & ${ }^{\mathrm{P}} 0,09921$ \\
\hline Pathological DES & ${ }^{\mathrm{P}}-0,4097 * *$ & ${ }^{\mathrm{P}}-0,01343$ & ${ }^{\mathrm{P}}-0,285$ & ${ }^{\mathrm{S}} 0,1826$ & ${ }^{\mathrm{S}}-0,08407$ & ${ }^{\mathrm{P}} 0,2231$ \\
\hline
\end{tabular}

${ }^{\mathrm{P}}=$ Pearson's $r{ }^{\mathrm{S}}=$ Spearman's $\mathrm{r} ;{ }^{* *} \mathrm{p}<0.01$

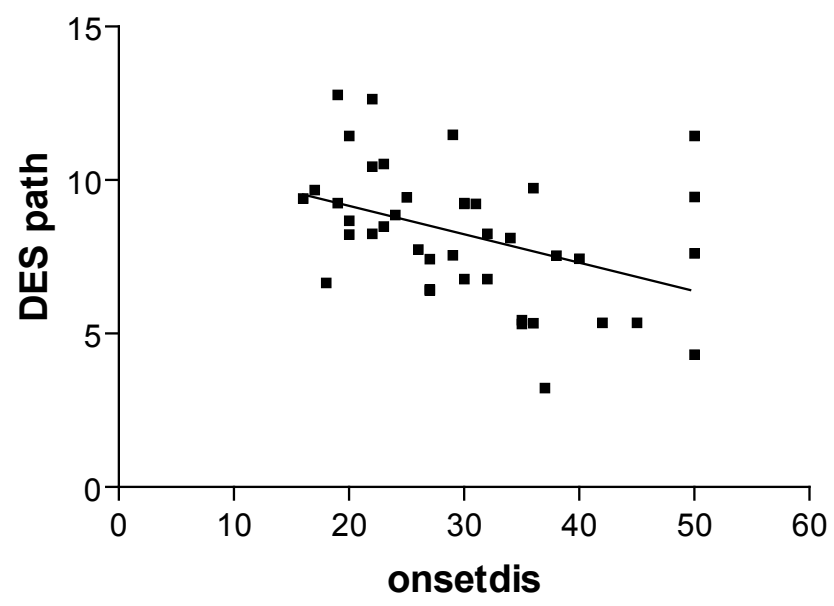

Fig. 3. Linear regression between onset of the disorder and DES-taxon.

There was also positive correlation between onset of the disorder and number of suicidal attempts.

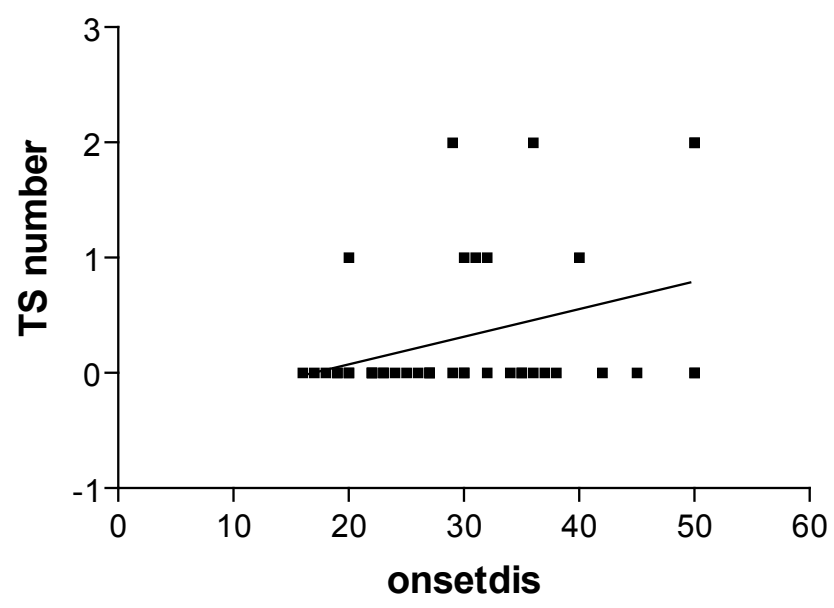

Fig. 4. Linear regression between onset of the disorder and number of suicide attempts.

\section{DISCUSSION}

Psychological dissociation assessed with the DES was higher in bipolar patients than in healthy controls. Patients also experienced severe psychological dissociative symptoms more frequently than healthy controls and their pathological DES scores were significantly higher than controls. If the disorder developed earlier, the level of pathological dissociation was higher. It is hard to say, if the dissociation precedes the bipolar disorder or that people with higher levels of dissociation fall ill earlier or if patients with earlier onset of the bipolar disorder dissociated more robustly than patients with later onset.

Our study was limited. There were statistically significant more females and a higher level of education in the control group than in the patient group. However, as we show in our analyses of gender and education impact on the level of dissociation, the gender and education had no significant impact on the results with the exception of male DES which did not differ significantly between controls and patients although the difference was of borderline significance $(\mathrm{p}=0.055)$.

To assess the level of dissociation, we used self-report questionnaires. Future research should corroborate these questionnaires with clinician-rated instruments.

A further limitation of our study is the relatively small patient sample size which made impossible the evaluation of different subgroups of patients with bipolar affective disorder. Patients, unlike controls, were medicated and possible side-effects could explain part of the differences between patients with bipolar affective disorder and healthy controls. But the correlation between the doses of each drug was not associated with the degree of dissociation. So far, however, is not known to antipsychotics or mood stabilizers increased dissociation. It is known only to tricyclic antidepressants.

We need further research to explore the role of dissociation in other affective disorders and its relation to childhood trauma, cognitive functions, emotional control, biological factors and therapy outcome.

\section{ACKNOWLEDGEMENT}

The study was supported by the research grant NT11047 IGA MZ $\breve{C R}$

\section{REFERENCES}

1. Tondo L, Albert MJ, Koukopoulos AE, Baethge Ch, Baldessarini RJ. Bipolar Disorder In: Tarazi FI \& Schatz JA (Eds.). Neurological and Psychiatric Disorders, Haman Press 2005;205-227.

2. Greenes D, Fava M, Cioffi J, Herzog DB. The relationship of depression to dissociation in patients with bulimia nervosa. $\mathbf{J}$ Psychiatr Res 1993;27(2):133-37. 
3. Lipsanen T, Saarijarvi S, Lauerma H. Exploring the relations between depression, somatization, dissociation and alexithymiaoverlapping or independent constructs? Psychopathology 2004; 37(4):200-206.

4. Maaranen P, Tanskanen A, Haatainen K, Honkalampi K, Koivumaa-Honkanen H, Hintikka J, Viinamäki H. The relationship between psychological and somatoform dissociation in the general population. J Nerv Ment Dis 2005;193(10):690-692.

5. Pastucha P, Prasko J, Diveky T, Grambal A, Latalova K, Sigmundove Z, Tichackova A. Borderline personality disorder and dissociation - comparison with healthy controls. Activitas Nervosa Superior Rediviva 2009;51(3-4):146-149.

6. Ross CA. Schizophrenia: Innovations in Diagnosis and Treatment. Birmingham, Haworth, 2004.

7. Pastucha P, Prasko J, Grambal A, Latalova K, Sigmundova Z, Tichackova A. Dissociative disorder and dissociation - comparison with healthy controls. Neuroendocrinol Lett 2009c;30(6):769-773.

8. Holowka DV, King S, Sahep D, Pukal M, Brunet A. Childhood abuse and dissociative symptoms in adult schizophrenia. Schizophr Res 2003;60:87-90.

9. Schäfer I, Harfst T, Aderhold V, Briken P, Lehmann M, Moritz S, Read J, Naber D. Childhood trauma and dissociation in female patients with schizophrenia spectrum disorders: an exploratory study. J Nerv Ment Dis 2006;194:135-138.

10. Spitzer C, Barnow S, Freyberger HJ, Grabe HJ. Dissociation predicts symptom-related treatment outcome in short-term inpatient psychotherapy. Aus N Z J Psychiatry 2007;41:682-687.

11. Glaslova K, Bob P, Jasova D, Bratkova N, Ptacek R: Traumatic stress and schizophrenia. Neurol Psychiat Brain Res 2004;11:205208.

12. Sar V, Taycan O, Bolat N, Ozmen M, Duran A, Oztürk E, ErtemVehid H. Childhood trauma and dissociation in schizophrenia. Psychopathology 2010;43:33-40.

13. Zanarini MC, Ruser T, Frankenburg FR, Hennen J: The dissociative experiences of borderline patients. Compr Psychiatry 2000;41:223-227.

14. Ball S, Robinson A, Shekhar A, Walsh K. Dissociative symptoms in panic disorder. J Nerv Ment Dis 1997;185:755-760.

15. Segui J, Marquez M, Garcia L, Canet J, Salvador-Carulla L, Ortiz M. Depersonalization in panic disorder: a clinical study. Compr Psychiatry 2000;41:172-178.

16. Gulsun M, Doruk A, Uzun O, Turkbay T, Ozsahin A. Effect of dissociative experiences on drug treatment of panic disorder. Clin Drug Investig 2007;27:583-590.

17. Praško J, Raszka M, Adamcová K, Kudrnovská H, Kopřivová J, Vyskočilová J (2008). Predikce terapeutické odpovědi v kognitivní behaviorální terapii u pacientů s obsedantně kompulzivn poruchou rezistentní na léčbu psychofarmaky. [(Prediction of the therapeutic response in cognitive behavioral therapy in patients with obsessive compulsive disorder resistant to the treatment with psychopharmacs) (In Czech with English abstract)] Psychiatrie 2008;12:( suppl 3):55-62

18. Raszka M, Praško J, Adamcová K, Kopřivová J, Vyskočilová J. Disociace a kognitivní funkce u obsedantně-kompulzivní poruchy - průřrezová studie. [(Dissociation and cognitive function in obsessive compulsive disorder - cross sectional study) (In Czech with English abstract)]. Česká a slovenská psychiatrie 2008;104:298296.

19. Raszka M, Kopřivová J, Novák T, Adamcová K, Praško J. Psychological dissociation in obsessive-compulsive disorder is associated with anxiety level but not with severity of obsessive-compulsive symptoms. Neuro Endocrinol Letters 2009;30(5):624-628.

20. Prasko J, Raszka M, Adamcova K, Grambal A, Koprivova J, Kudrnovská H, Latalova K, Vyskocilová J. Predicting the therapeutic response to cognitive behavioral therapy in patients with pharmacoresistant obsessive-compulsive disorder. Neuro Endocrinol Letters 2009;30(5):615-623.

21. Basso MR, Lowery N, Neel J Purdie R, Bornstein RA: Neuropsychological impairment among manic, depressed, and mixed-episode inpatients with bipolar disorder. Neuropsychology 2002;16:84-91.

22. Thompson JM, Gallagher P, Hughes JH, Watson S, Gray JM, Ferrier IN, Young AH. Neurocognitive impairment in euthymic patients with bipolar affective disorder. Br J Psychiatry 2005;186:3240.

23. Garno JL, Goldberg JF, Ramirez PM, Ritzler BA. Impact of childhood abuse on the clinical course of bipolar disorder. $\mathrm{Br} \mathrm{J}$ Psychiatry 2005;186:121-125.

24. Guy W (ed.): ECDEU Assessment manual for psychopharmacology. Rockville, U.S. DHEW 1976.

25. Carlson EB, Putnam FW, Ross CA, Anderson GG, Clark P, Torem Coons $\mathrm{P}$, et al. Factor analysis of the Dissociative Experiences Scale: A multicenter study. In BG Braun \& EB Carlson (Eds.). Proceedings of the Eighth International Conference on Multiple Personality and Dissociative States. 1991; Chicago: Rush.

26. Carlson EB, Putnam FW. An update on the Dissociative Experience Scale: An update on the Dissociative. Dissociation 1993; 6:16-27.

27. Ptacek R, Bob P, Paclt I, Pavlat J, Jasova D, Zvolsky P, Raboch J. (2007). Psychobiology of dissociation and its clinical assessment. Neuro Endocrinol Lett 2007;28(2):191-98.

28. Waller, NG., Putnam, F.W., Carlson, E.B. (1996): Types of dissociation and dissociative types: A taxonometric analysis of dissociative experiences. Psychological Methods 1996;1(3):300-321.

29. Woods SW. Chlorpromazine equivalent doses for newer atypical antipsychotics. J Clin Psy 2003;64(6):633-7. 